\title{
ASSESSING TOURISM POTENTIALS OF THE WINE ROUTE REGION IN MACEDONIA
}

DOI: http://dx.doi.org/10.18509/GBP.2016.32

UDC: 338.48-44:663.2(497.7)

\section{Associate Prof. PhD. Biljana Petrevska}

Faculty of Tourism and Business Logistics, Goce Delcev University - Stip, Macedonia

\begin{abstract}
The article makes an effort to assess tourism potentials of the Wine route region in Macedonia. For that purpose, in the first line it investigates the current level of tourism development by analyzing the major problems and obstacles which prevent this region from becoming more developed in tourism manner. The results were obtained from a field survey undertaken as a part of broader research conducted in 2014. The data were collected by a self-administered questionnaire distributed among managers and employees of 11 wineries located along the Povardarie region (Demir Kapija, Kavadarci, Gradsko, Negotino and Veles). The overall conclusion is-the Wine region has numerous weaknesses that need to be addressed and various profound limiting factors that prevent its tourism development. Therefore, the current tourism strategy needs an improvement in terms of overcoming the spotted obstacles generally by identifying and introducing a unique tourist product.
\end{abstract}

Keywords: Tourism development; Wine route region; Macedonia.

\section{INTRODUCTION}

Many regions have realized the benefits for wine tourism development. Yet, wine regions do not automatically transform into wine tourism destinations. What is required for a successful wine tourism region is actually a significant investment of time, money and efforts.

The objective of this paper is to evaluate the current stage of tourism development of the Wine route region in Macedonia. In particular, the paper attempts to explore and identify the major problems and weaknesses that need to be addressed. The focus is put on the major opportunities for improvements, particularly formulating the sector vision of change and the vision of change for products and services, as well as the possibility for reaching the vision of change by the identified interventions. The paper is structured in several parts. After the introductory part, Section 2 provides a brief overview on literature addressing the issues of wine tourism, wine routes and tourism development. Section 3 provides some stylized facts for the Wine route region with elaborate regional and local context. Section 4 presents the tourism market map of the wine route region, while Section 5 encompasses the research methodology. The analysis, results and discussion are noted in Section 6, while some future challenges and recommendations are presented in the final section.

The general contribution of the study is the fact that it enriches the poorly developed academic work in this issue regarding the wine route region development in Macedonia with certain exceptions [11]. Furthermore, the study provides recommendations to the key tourism players to introduce a new strategy and a vision of change in the line of 
facilitating the increased investment, income and employment in both the wine and tourism sectors of the region. Its aim is also to encourage tourists to visit the investigated wine region and to experience all it has to offer.

\section{LITERATURE REVIEW}

Academic research into wine tourism, wine routes and tourism development has accelerated particularly over the last decade. So, now there is an extensive body of knowledge on wine tourism phenomenon, wine tourism markets and products.

Wine tourism has been defined as 'visitation to vineyards, wineries, wine festivals and wine shows for which grape wine tasting and/or experiencing the attributes of a grape wine region are the prime motivational factors for visitors' [8]. This market-based definition has informed a proliferation of many studies [1], [2], [3], [5], [6], [7], [9], [10] and [12] whereas the accent is on the wine tourist products, wine activities, consumption, as well as on the events and places that comprise wine tourism.

Generally, two major approaches have emerged in the literature related to framing wine tourism [4]:

i. Macroeconomic approach, being framed at national level (marketing and branding; export revenue; tourism trends; funding; etc.) and regional level (regional identity; infrastructure; role of local government; etc.); and

ii. Microeconomic approach, being framed at the level where wine tourism takes place (the winery and consumer).

\section{WINE ROUTE REGION IN MACEDONIA}

The wine tourism in Macedonia is relatively new type of tourism, which is identified in several strategic documents. One of them is the up-dated National Strategy for Tourism Development 2011-2015. Here the wine tourism is defined as a separate cluster for regional tourism development. The reasons for such a delay, lays in the fact that the wine was not observed as a possibility for economic development in terms of application as material and spiritual cultural heritage. It is believed that side by side with France, Italy and Spain, Macedonia belongs to the so called "old wine countries".

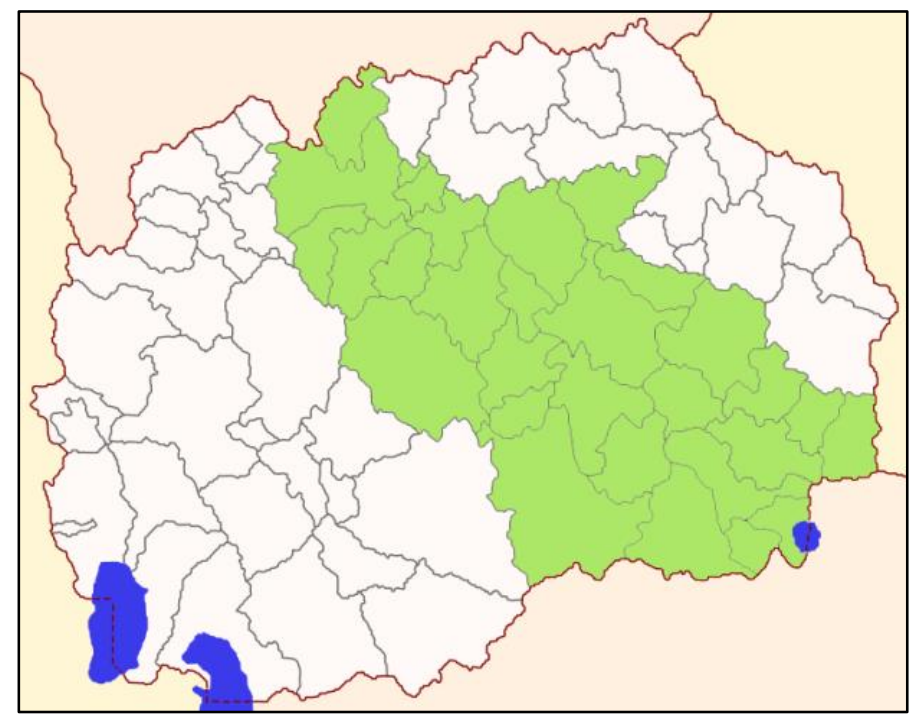

Figure 1. Wine route region in Macedonia 
The "wine tourist product" of the Wine route region is generally offered to tourists as part of some other tourism supply or as a day excursion. The offer consists of tasting different wines, tours in the production area, some history lessons, stories, as well as good traditional catering and shopping possibilities. Some of the wineries have accommodation facilities and some provide just catering and wine tasting. The most visitor traffic is generated directly, rather than through travel agencies and tour operators urging the need for more aggressive promotion of the wine tourism product.

The wineries in Macedonia are dispersed in three main regions: (1) Povardarie - Vardar Valley (central region); (2) Pcinja - Osogovo (east region); and (3) Pelagonisko Poloski (west region).

Povardarie is the largest and most famous vineyard region in Macedonia (Figure 1), known as the Wine route region in Macedonia. The geographical representation of the wineries is identical to the representation of the vineyards, where most companies are located in the central region of the Vardar Valley. Hence, the potentials for development of wine tourism are within Povardarie. The destination covers $16 \%$ of the national territory mostly spread over rural municipalities. The population density is very low being only 38 inhabitants $/ \mathrm{km}^{2}$. The general unemployment rate is $43.9 \%$ (higher than the national rate of 29\%), while the unemployment in services is $47 \%$. The positive light can be seen in people's willingness to set up their own businesses due to the governmental activities and support. However, the absence of foreign language proficiency is an obstacle for further tourism development. The climate is favorable for development of agriculture, especially viticulture. The region can be reached by road, train or by nearby national airport in Skopje.

During the past, vast majority of the wineries produced wine that was sold as bulk without any efforts to build a brand out of the Macedonian wine. The production of the bottled wine was marginalized. Nowadays, the wineries are investing in equipment upgrade, reconstruction and human resource development as the Macedonian wine industry makes the switch from bulk to bottled wine production. They are investing in all aspects of marketing and cooperate with the central government in order to promote the Macedonian wine. Yet, despite the significant improvements, there is still much to do.

\section{MARKET MAP OF THE WINE ROUTE REGION}

Based on the Making Markets Work for the Poor (M4P) methodology, the market map for the Wine route is given in Figure 2. It is noticeable that it is comprehensive since many of the supporting functions may be used in the line of supporting and enhancing sustainable development.

Generally, all tourism activities within the Wine route region are driven by the actors at regional level. The Center for development of the Vardar Planning region makes efforts for raising awareness and funds for developing wine tourism in this region. The intention is to combine transit, cultural and wine tourism and to create a complex and unique tourism product. The Chambers of Commerce undertakes activities for promoting the Macedonian business environment and increasing sales of Macedonian products on the global market. The "Tikves Foundation" plays crucial role in the line of initiating activities for organizing wine trials that will be connected into a cohesive product. Although this foundation tries to collaborate with the Tourism Cluster, the undertaken activities so far are modest due to limited resources. In the frames of the Macedonian Competitiveness Activity Project a solid base for future development of wine tourism in the region is set. 


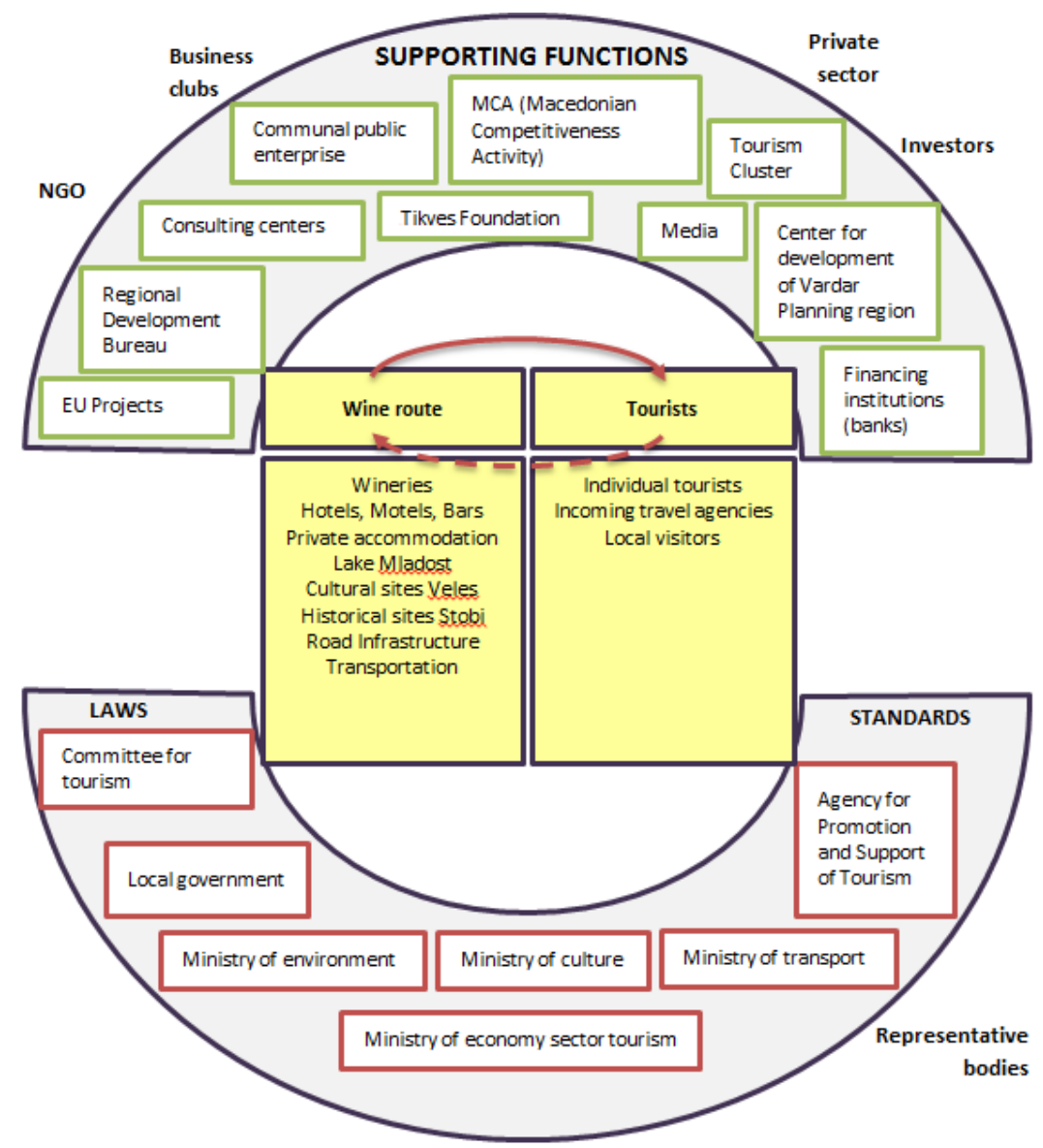

Figure 2. Market map of the Wine route region

\section{METHODOLOGY AND RESEARCH FRAME}

In order to evaluate the current tourism development of the Wine route, a field survey was undertaken as part of broader research conducted during the period 11-19 July, 2014. A self-administered questionnaire was distributed among managers/owners and employees of 11 wineries located along the Wine route region of Povardarie (Demir Kapija, Kavadarci, Gradsko, Negotino and Veles). The respondents were well informed about the aims of the survey ahead of time in order to avoid any attempt to manipulate the survey process and possibly bias the results.

A total of 40 questionnaires were distributed, out of which 34 were usable (the rest were incomplete), yielding an overall response rate of $85 \%$. During the field research it was detected that the winery "Grkov" was closed due to negative business results, and that the same owner opened a new one (winery "Chateau Sopot") in the near vicinity. Furthermore, the winery "Tikves" was excluded from the field survey due to their unwillingness to be part of the research. So the following wineries were surveyed:

○ Demir Kapija: "Radevski", "Elenov" and "Popova Kula";

○ Kavadarci: "Popov", "Donov", "Cekorovi”, "Iliev" and "Gligorovi”;

○ Gradsko: "Stobi";

- Negotino: "Bovin"; and

○ Veles: "Chateau Sopot". 
According to the working position of the respondents, the structure is $71 \%$ employees, $23 \%$ managers, and $6 \%$ winery owners. Due to the fact that the majority of the employees in the wineries are men, the gender structure of the respondents was $88 \%$ male and $12 \%$ female. All respondents were Macedonians with an average age of 38 .

\section{ANALYSIS, FINDINGS AND DISCUSSION}

\section{Supporting functions/services}

Only half of the investigated wineries in the destination have accommodation capacities with an average of 26 rooms per facility. Almost $60 \%$ of the wineries which offer accommodation services do not have a star classification of the facility, although are fully aware that it helps in attracting guests and their number increase. This means, it is under a four-star classification providing good quality of accommodation service. The restaurant facilities offer food and beverage services with an average of 122 seats. Besides enjoying the stay and good wine, the visitors may use additional services in the nearby vicinity (Negotino, Kavadarci, Veles or Demir Kapija), like pharmacy, emergency healthcare, a car-mechanic, police and fire fighting department. According to the suppliers, the tourist attractions and locations in the destination are easily accessible for tourists, but are not well marked. There are also numerous services missing in the supply chain in terms of tourists' satisfaction. The destination requires regular public buses or van transportation to/from the wineries. There are no public parking plots, public toilets nor public waste disposal. The wine region is missing a tourist information office as well.

\section{Problems and underlying causes}

The field survey revealed several problems, which could be considered to be large obstacles for tourism development of the Wine route. The average price of the most common service per person that the facilities sell is up to $50 \mathrm{EUR}$, which initiates a necessity of improving the services in terms of "better served-better paid". There is an absence of accommodating opportunities within half of the facilities. Domestic travel agencies and foreign tour-operators are not sufficiently used as intermediaries in the line of increasing the market. Despite the fact that half of the surveyed wineries receive subsidies from the state and thus support their business performance, the access to finance is identified as one of the top-3 limitations to the facilities development. The second limiting factor refers to their promotion onto foreign markets and cooperation with foreign partners. This is another limitation mutually identified by the managers and the employees of the wineries. Yet, a slight difference is noted concerning the third limitation. According to the managers, the economic situation in the country is a strong limiting factor in the facility development. This is not the case with the employees, who disregarded the economic situation and omit it from the ranking in favor of the specialization at the workplace.

The number of visitors to the facilities in the last two years is very unsatisfactory (3 persons/day in small wineries, and 14 persons/day in large wineries). Only 50-60\% of the visitors are foreign tourists, which leads to a very modest multiplier effect. Generally, the foreign tourists come from neighboring countries (Greece, Serbia, Bulgaria, Albania and Kosovo), although there are also foreigners from other European countries and worldwide. One may find Macedonians from the diaspora as visitors to the destination, as well. All in all, the visitors stay up to 1 day and very rarely 2-3 days. They visit the facilities by car and bus, and occasioanlly by train and plane. 
The unfavorable economic situation in Macedonia in general, particularly in this region, leads to low payment in tourism. An interesting note may be underlined concerning the issue that working in tourism is safe and secure. Namely, the male respondents have dilemma whether to agree or disagree, while the female employees do not perceive it as safe and secure. According to the working position, the managers of the wineries disagree unlike the surveyed owners who find it safe and secure the same as the majority of the employees. This leads to conclusion of having unclear picture referring this issue.

Despite the unavailability of funding resources especially if a woman-enterpreneur runs the winery, some overall obstacles for tourism businesses are detected. Yet, there are slight differences in the perception among different target groups. While the owners are neutral, the managers agree. On the other hand the employees have a dilemma whether to agree or to be neutral. In case when making a gender cross-tabulation, one may note that neither men nor women can decide either to be neutral or to agree. However, there is no dilemma for the youth who disagree that this can be an obstacle. Furthermore, closely linked to the previous statement is the one regarding the membership of women in the Tourism Committee. Namely, the overall perception is that by supporting women's involvement in a tourism institution, one may improve the position of women entrepreneurs in tourism. Both genders, agree to strongly agree with this statement, as well as the youth and the employees. Only owners/managers are neutral and are not convinced in the potentially positive reflection concerning this issue.

\section{Core Value Chain}

The supply side of the destination is consisted of continuous growing number of officially registered wineries (from 54 in 2008, to 81 in 2013). Yet, some of them stopped their production due to the negative business results such as the winery "Grkov" from Kavadarci. Today, the following wineries are among the most active within the Wine route region: "Tikves", "Popov", "Trajkovski”, "Popova Kula", "Elenov", "Stobi", "Bovin"and "Chateau Sopot" (opened by the same owner of the winery "Grkov", but on other location). These wineries produce $85 \%$ of the total wine production of Macedonia with different annual production. $5 \%$ of the surveyed wineries produce up to 50,000 liters, $35 \%$ produce up to 75,000 liters, $25 \%$ produce up to $1,300,000$ liters, and $35 \%$ produce up to 7,000,000 liters of wine per year.

The wineries are affiliated in a cluster and make joint offer. The small wineries export abroad up to $40 \%$ of the annual production, while large wineries export up to $70-85 \%$. All wineries that are active within the Wine route region possess an appropriate working certificate. Some of them are fresh to the market, but some have 10 even 15 years of experience. The smaller wineries have an approximate annual income up to 50,000 EUR in the last two years, but the larger ones have earned more than 600,000 EUR. The number of employees ranges from few to over 40 employees and in most cases the employees have secondary education. Half of the investigated wineries receive subsidies from the state, share good opinion on its impacts on the business performance and relatively satisfactory distribution among tourism actors. The facilities use various different marketing channels for promotion of their offer, like: Internet, social networks, print media, TV and radio advertising, billboards, direct communication and sponsorship. Yet, the tourism supply of the Wine route region as a destination is not well promoted via Internet.

The surveyed respondents perceive that the good 'seasons' for destination's development in terms of tourism is summer (due to the mobility of tourists transiting the region) and autumn (due to the "grape period"). The utilization of the capacity within the season is estimated from 
$80-100 \%$, while out the season the wineries work approximately with $20-30 \%$ of the capacity. Being aware of the negative effects of seasonality on tourism business, they take measures and activities for overcoming it, but with modest and limited results.

\section{CONCLUSIONS AND RECOMMENDATIONS}

Upon detailed field survey and literature review related to the destination's tourism development, it may be concluded that the Wine route region of Povardarie has very modest tourism results. The region is faced with many challenges since the lists of weaknesses and threats for tourism development are long and substantial. Yet, some competitive advantages may be found in quality of services, low service prices and natural beauties. As a good starting point for further improvement of the destination in tourism manner, one may take in consideration several elements, prioritized to their importance for tourists visiting the destination. Natural beauties, cultural events and traditional food are detected as items for enhancing current tourism supply of the Wine route region. Furthermore, being affiliated in a cluster gives a positive light for improvements of the current joint supply with other wineries from the wider region. What is worth noticing here is the export data-up to $45 \%$ of the annual production for small wineries, and up to $70-85 \%$ for large wineries. This presents a solid initial base for strengthening the wine entities in a broader foreign market. The "Tikves Foundation", along with the initiatives of the Center for development of Vardar Planning region and the isolated private initiatives, may have crucial role in promotion of the necessity of introducing wine tourism to the destination in more effective manner.

There is a need to identify measures and activities that will contribute to create more competitive tourism sector, as well as to enable systematic change in terms of improving tourism services offered in the Wine route region. Namely, there is a necessity of promoting the "wine tourism product" and the region in general to the specific groups of visitors (winelovers, adventure-tourists etc.). The solution may be found in creation of sophisticated software modules for wine tourism promotion. Furthermore, the market players should contribute much more in terms of coordinating the wine tourism activities. In this line, improvement of tourism competitiveness may be found in strengthening the coordination with the local government, cooperation with foreign partners, and presence of political will as well as raising the awareness of local inhabitants concerning the positive effects of wine tourism development.

The vision of change of services perceives interventions in more systematic approach. Therefore, the priority strategic action is seen in improvement of the knowledge and behavior of employees in tourism sector of the region. Despite the overall unfavorable economic situation in the country and the low payments in tourism, one may create an environment for stable and high performance employment. Developed complex and unique "wine tourism product" is the final vision of change perceived for the Wine route region.

\section{REFERENCES}

[1] Alant, K. \& Bruwer, J. Wine tourism behaviour in the context of a motivational framework for wine regions and cellar doors. In: Carlsen, J. and Charters, S. (eds) International Wine Tourism Research. Proceedings of the International Wine Tourism Conference, Margaret River, Western Australia, May 2004. Vineyard Publishers, Perth, Australia, 2004. 
[2] Bruwer, J. \& Alant, K. The hedonic nature of wine tourism consumption: an experiental view, International Journal of Wine Business Research, 21(3), pp. 235-257, 2009.

[3] Carlsen, J. Segmentation and profiling of the wine festival visitor market. In: Cullen, C., Pickering, G. and Phillips, R. (eds) Bacchus to the Future: The Inaugural Brock University Wine Conference, St Catharines, Ontario, Canada. Brock University Press, St Catharines, Ontario, Canada, pp. 257-278, 2002.

[4] Carlsen, J. A review of global wine tourism research, Journal of Wine Research, 15(1), pp. 47-57, 2004.

[5] Charters, S. \& Ali-Knight, J. Who is the wine tourist?, Tourism Management 23, pp. 311-319, 2002.

[6] Fountain, J. \& Charters, S. Younger wine tourists: a study of generational differences in the cellar door experience. In: Carlsen, J. and Charters, S. (eds) International Wine Tourism Research. Proceedings of the International Wine Tourism Conference, Margaret River, Western Australia, May 2004. Vineyard Publishers, Perth, Australia, 2004.

[7] Getz, D. Explore Wine Tourism: Management, Development and Destinations, Cognizant Communication Corporation, New York, 2000.

[8] Hall, C. M., Longo, A. M., Mitchell, R. \& Johnson, G. Wine tourism in New Zealand. In: Hall, C.M., Sharples, L., Cambourne, B. and Macionis, N. (eds) Wine Tourism around the World: Development, Management and Markets. Elsevier Science, Oxford, UK, pp. 150-176, 2000.

[9] Heaney, L. Tapping the barrel: profiling domestic wine tourists, 1998-2001, BTR Tourism Research Report, 5(1), pp. 39-43, 2003.

[10] Pan, F. C., Su, S. J. \& Chiang, C. C. Dual attractiveness of winery: atmospheric cues on purchasing, International Journal of Wine Business Research, 20(2), pp. 96-110, 2008.

[11] Petrevska, B. \& Ackovska, M. Tourism development in Macedonia: evaluation of the Wine route region, Ekonomika - Journal of Economic Theory and Practice and Social Issues, 3/2015, pp. 73-83, 2015.

[12] Williams, P. Positioning wine tourism destinations: An image analysis, International Journal of Wine Marketing, 13, pp. 43-59, 2001. 